\title{
An Opinion on Spring Habitats within the Earth's Critical Zone in Headwater Regions
}

\author{
Martin Reiss * (D) and Peter Chifflard \\ Department of Geography, Philipps-Universität Marburg, 35037 Marburg, Germany; \\ peter.chifflard@geo.uni-marburg.de \\ * Correspondence: reissm@geo.uni-marburg.de; Tel.: +49-6421-28-24381
}

Received: 17 July 2017; Accepted: 25 August 2017; Published: 29 August 2017

\begin{abstract}
Springs are crucial interfaces within the Earth's Critical Zone, connecting water and its related matter and energy at different scales from the microscopic to the macroscopic level. This connectivity is of importance for habitat conditions and the invertebrate community in springs as ecotones at the groundwater-surface water and the aquatic-terrestrial interfaces in headwater regions. Here, an integrative approach regarding an appropriate theoretical framework is given as an opinion on coupling perspectives from Ecohydrology and Earth Science. A theoretical integration within the approaches of the concepts of Earth's Critical Zone and Hydropedology with its hierarchical framework is considered for bridging multiple scales from the individual substrate type to the entire spring habitat and the headwater catchment. The paper is in every respect an opinion on theoretical approaches and provides a synthesis within a conceptual framework for spring habitats, which should give further insight into how to study such small water bodies in the context of its adjacent landscape settings.
\end{abstract}

Keywords: ecohydrology; hydropedology; hierarchical framework; ecotone; groundwater; interflow

\section{A Spring Is a Spring Is a Spring}

A spring is where groundwater discharges to the ground surface creating a visible flow [1,2]. Springs form headwater streams as an integrative part of headwater regions and their water network systems. Classifications of spring habitats vary according to their specific features and environmental characteristics [1,3-5]. Springs are typified by high water clarity, a relatively constant water temperature, and chemical conditions focusing on temperate cold springs [6]. The water temperature regime determines a basic classification of springs based on mean annual air temperature for a regional catchment. Ambient springs (also called non-thermal springs or cool springs) are characterized by a water temperature that is approximately equal to the mean annual air temperature $[7,8]$. The term cold springs should be reserved for springs with temperatures below mean annual air temperature [9]. There is a lack of consensus regarding the exact temperature that distinguishes an ambient spring from a thermal spring. It would be consistent to describe thermal springs as those with a water temperature above the mean annual air temperature, but several other thresholds exist, e.g., a division between a non-thermal and thermal spring at $20{ }^{\circ} \mathrm{C}$ or the human body temperature $[3,10]$. A fundamental geochemical classification can be made based on the calcium carbonate content, which directly influences the alkalinity of spring water. Generally, springs can be categorized as calcareous springs if the bedrock is entirely or partially composed of calcium carbonate, and siliceous springs if the bedrock is acid igneous or other bedrock that does not contain calcium carbonate [11]. Calcareous and siliceous springs are characterized by different plant communities [12]. Hydrochemical differences are of crucial importance for the distribution of some organisms, such as diatoms or lichens $[13,14]$. Specific taxa can, in fact, serve as potential indicator species for calcareous 
and siliceous springs. Springs and small headwater streams-which are also influenced by associated groundwater-surface water ecotones, such as the hyporheic zone [15] - are important supply systems for carbon and nutrient processing, and are consequently sources of water, nutrients, and species for downstream reaches [16,17]. Another ecological property that springs and headwater streams have in common is a close terrestrial-aquatic linkage; both tend to be very sensitive to natural and anthropogenic disturbances regarding impacts from their surrounded catchments in headwater regions [18]. Nevertheless, community metabolism, temperature, and major chemical constituents are generally classified as essentially constant for springs [19]. The invertebrates evolved in normally cold water springs depending on these specific environmental features lead to a limnological grouping of three different classes of stenotypy in relation to a habitat specific binding. Crenobionts only live in springs, and can be characterized within a small range in ecological valence. Crenophiles mainly live in springs, but also exist in other environments under similar conditions and have a wider range in ecological valence (e.g., springbrook). Crenoxenes are ubiquitous species that occasionally live in springs [20]. Springs are hence highly important habitats for global biodiversity. Under pristine conditions, springs are insular hotspots of regional diversity, harboring specialists as well as aquatic and hygrophilous generalists [21]. Springs are multiple three-way ecotones that link terrestrial and aquatic habitats, ground and surface waters, and the spring and headwater stream in a four-dimensional framework (longitudinal, lateral, vertical, and temporal; [9]). Local topological conditions, such as the degree of slope inclination, and hydromorphological properties, such as flow velocity and turbulence (lotic and lentic aquatic ecosystems), determine limnological spring classification [22]: (1) rheocrenic springs with fast flowing or falling water; (2) helocrenic springs with diffuse or laminar flowing water; and (3) limnocrenic springs with a still water pool [23,24]. So far, limnological-ecological research has focused on the entire habitat of a spring more or less as a substrate complex, in comparison to other aquatic habitats, to determine stenotypy and describe key factors mainly driving species distribution $[25,26]$. However, there is evidence of spatial heterogeneity at the microhabitat scale, especially when a significant relationship between biodiversity and substrate type occurrence and richness is obvious [9]. Substrate is an important ecohydrological component that influences the occurrence, adaptation, survival, and reproduction of the springhead fauna [27]. Some concepts of a hierarchical framework for a multi-scale and process-oriented classification of rivers and its habitats exist [28-31]. Hierarchical frameworks have been developed for river management purposes, and have been used for mapping habitat quality at different spatial scales. The development of similar approaches for spring ecotones has been poor or fragmented [4]. A new conception of classifying springhead habitats as ecotones with an integration of sampling methods focusing on the habitat and microhabitat scales was recently presented (Springscape; [32]).

In this paper, we seek to demonstrate the importance of springs as key interfaces and their role within the holistic framework of Earth's Critical Zone and the theoretical concept of Hydropedology.

\section{Spring Habitats within the Context of Earth's Critical Zone and Hydropedology}

In the following, an explanation of concepts related to Earth's Critical Zone, Hydropedology, and Springscape are given regarding the context to spring ecotone. This will be carried out to disclose the ecological importance of spring habitats and their particular relevance as filters and connectors within the landscape, although springs are small water bodies and often ignored as autonomous aquatic habitats.

\subsection{Earth's Critical Zone and Spring Habitats}

The Earth's Critical Zone (CZ) is allegorized as a skin [33] or veneer [34] of planet Earth from the top of the vegetation to the bottom of the aquifer (Figure 1). 


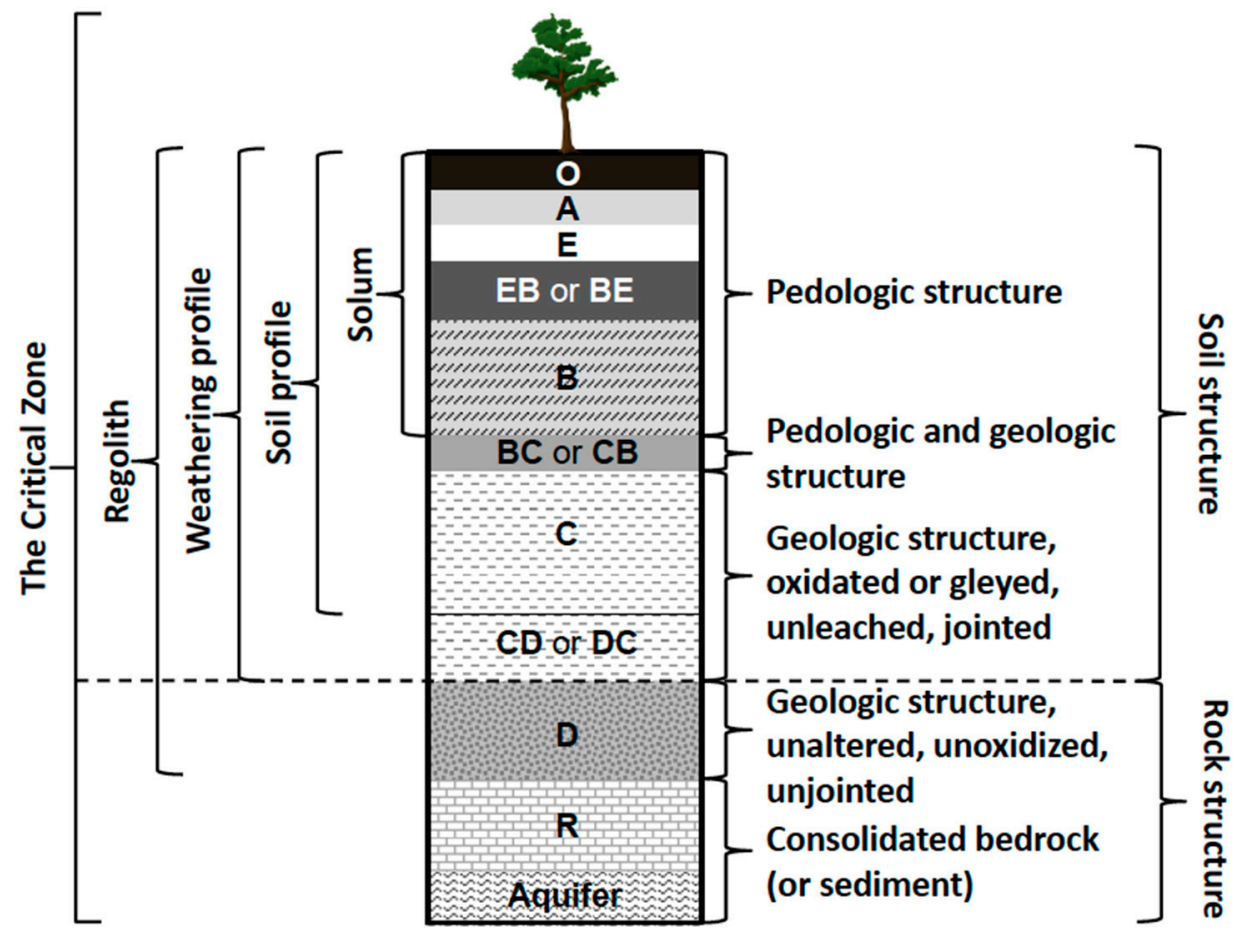

Figure 1. Critical Zone Concept modified from [35]. The D horizon is the unmodified, unweathered part of the C horizon [36]. Transportable material above fresh unweathered bedrock is called regolith [37].

The US National Research Council (NRC) defines the CZ as "a heterogeneous, near surface environment in which complex interactions involving rock, soil, water, air, and living organisms regulate the natural habitat and determine availability of life sustaining resources" [38]. The CZ is also considered a "feed-through reactor" [37], where inputs of solar energy and processes in the atmosphere with its gases and depositions interact with biota, soil, and rock to provide ecosystem services. The authors in $[34,39]$ illustrate these processes within an hourglass and emphasize that the $\mathrm{CZ}$ is controlled by chemical, physical, and biological processes influencing water flow, solutes, gases, and sediments. The concept is called critical, because it supports life, supplies resources, and yields materials to humans, and it has the capacity to unleash hazards [40]. It is accordingly an integrative approach in which several geospheres are cross-linked at their boundaries or interfaces: atmosphere, biosphere, pedosphere, lithosphere, and hydrosphere [35]. The Anthroposphere is not explicitly mentioned here, but human impacts or perturbations are considered [39,41]. Therefore, a complex and heterogeneous environmental system is built up within a conceptual theoretical framework of an interactive, vertically layered system (cf. Figure 1) [35,38]. However, the almost entirely pervasive hydrosphere cannot accurately fit in a layered system approach like the pedo- or lithospheres can, especially when an understanding of the processes in the $\mathrm{CZ}$ is necessary, which are dependent upon time, space, and scale $[33,42]$. Due to the nature of water in a closed earth system, the hydrological cycle is a crucial connector at environmental interfaces called the geospheric boundaries. Therefore, Ref. [35] argues that water is the key conduit for mass and energy transfer. The CZ operates as a living filter for Earth's hydrologic and biogeochemical cycles [42]. The relationships and interactions of rock, soil, water, air, and living organisms predominantly take place at geospheric boundaries, which are the key interfaces in the CZ [35]: the land surface-atmosphere boundary, the soil-vegetation boundary, the vadose zone-groundwater boundary, the surface water-groundwater boundary, the soil-stream boundary, and the soil-bedrock boundary. Springs are an important ecotone at the surface water-groundwater boundary [43] and an integrative key element within the CZ. As outlets of their subsurface catchments, springs are spatially and temporally integral for monitoring the groundwaterand interflow-related processes in headwater regions and substance flow within biogeochemical 
cycles [44] (cf. Figure 2). These interfaces are also critical, because flux transfers at those transitional boundaries have to interact between different variable and dynamic system compartments [34]. This criticalness requires inter- and multidisciplinary research because of the interconnectedness of diverse cycles in the earth system: the hydrological cycle, the geochemical cycle, the carbon cycle, the nutrient cycle, gas exchange, erosion and deposition, weathering, lithification, soil formation and genesis, life processes, and human impacts [35]. Understanding, predicting, and managing the environmental processes that define the natural capital of the $\mathrm{CZ}$ is now one of the most pressing societal challenges of the 21st century [45]. Over the next few decades, global climate change, the sequestration and exchange of carbon, and the impacts of land use and demographic changes will be pressing scientific issues [38].

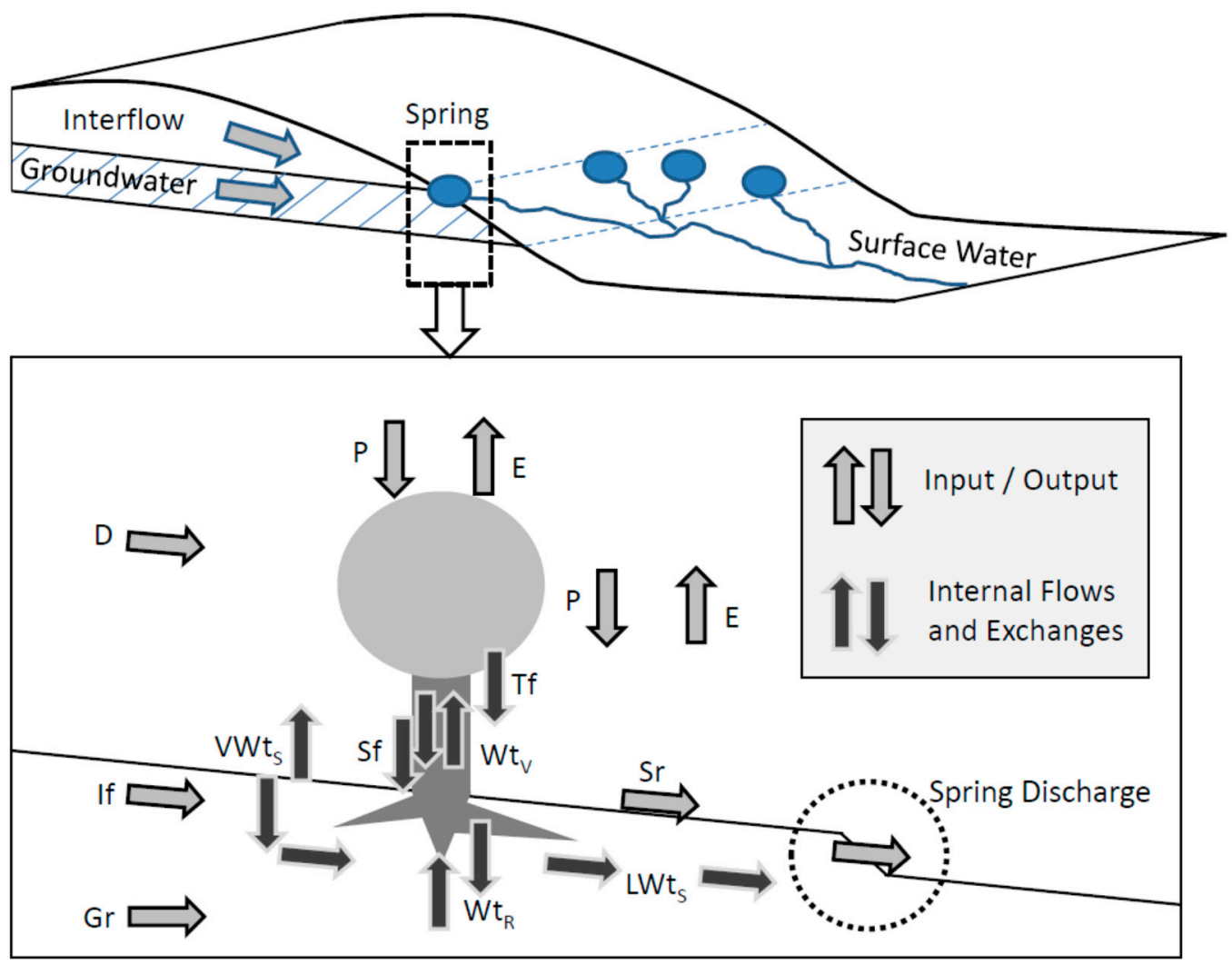

Figure 2. Schematic illustration of substance flows in a headwater region above a spring outlet. In- and Outputs are controlled within the water cycle. Internal flows should represent matter fluxes within the corresponding cycles, mostly at different interfaces (e.g., the soil-atmosphere or root/vegetation-soil interfaces). P: precipitation; E: evaporation (evapotranspiration); D: Deposition; Sr: Surface runoff; If: Interflow; Gr: Groundwater runoff; Tf: Through flow; Sf: Steam flow; $W t_{\mathrm{V}}$ : Water exchange (vegetation); $\mathrm{Wt}_{\mathrm{R}}$ : Water exchange (root-soil); $\mathrm{VWt}_{\mathrm{S}}$ : Vertical water exchange (soil-atmosphere); $\mathrm{LWt}_{\mathrm{S}}$ : Lateral water exchange (soil). Inspired by [46].

Spring discharge is much more than groundwater runoff to the surface. Systematically, it is complex because it is influenced by different factors (Figure 2). Here, the process-based approach of the ecotone concept is consistent with the concept of the $\mathrm{CZ}$, as spring ecotones play an important role in regulating the flows of material and information between surface landscapes and extensive aquatic systems [47]. Internal flows within hydrological compartments, such as vegetation, soil surface, root zone (soil), unrooted soil, and aquifer and surface water, can be distinguished as intra-compartmental processes, while inter-compartmental processes are inputs and outputs within the entire landscape water cycle (e.g., within a single watershed) as an open hydrological system (cf. compartment model of the landscape water cycle; [48]. The exchange of water and matter between these compartments are 
functional interchanges between CZ boundaries [49]. The schematic illustration of substance flows in headwater regions (Figure 2) also depicts the context of surface and subsurface hydrological processes related to soil. No spring discharge is consistently composed of pure groundwater, rather spring flow generation is an integrative process similar to streamflow generation. Groundwater proportions in spring flow range from $2 \%$ to $100 \%$ overall [50]. Interflow and surface flow also contribute to spring discharge and its geochemical components. However, spring flow may integrate different sources of water, including, but not limited to, groundwater [50]. Geochemical processes in the unsaturated zone of the soil may influence the quality of spring water, so soil structure is, by extension, important because soil properties can affect internal water flows (vertical and lateral water exchange within the soil; cf. Figure 2).

\subsection{Hydropedology and Spring Habitats}

Soil is a crucial part of the $\mathrm{CZ}$ and is a completely integrated layer or geomembrane [35]. The latter suggests a relative permeability of the pedosphere, which also includes the function of temporal matter and water storage in soils. Water is another essential part of the $C Z$, which is not only a layer (e.g., groundwater) but also an ever-present medium. Here, [51] describes the advantageous integration of pedology and hydrology for studying the intimate relationships between soil, landscape, and hydrology: Hydropedology [35,52] (cf. Figure 3). In situ soil development (soil architecture) and the soil-landscape relationship are two important features for understanding flow and transport processes across scales. Two primary aggregated scales can be separated: (1) the hillslope and landscape scale, whereby soil is considered a geographic subdivision of a landscape, or a Soilscape [53]; and (2) the regional and global scales, mostly associated with soil maps containing soil-type zones over larger areas, resulting from climate and vegetation gradients. The authors in $[35,54]$ provide a concept for structuring and grouping catenas as useful model examples for interpreting soil patterns and related regular trends in soil chemical properties on the landscape scale. Here, geomorphological and stratigraphic, hydrologic, and pedologic approaches are the most promising way to study soil distribution over the landscape regarding their controls on landscape hydrology [54]. Other authors suggest that bridging the gap between traditional pedology and soil physics and hydrology could result in synergies to enhance integrated studies of soil-water relationships [55-57]. As water seeps through soil, the transfer processes of solutes into and out of the soil-water solution become important for the transportation and transformation of material. Such heterogeneous reactions drive the evolution of particle surfaces and their biogeochemical reactivity, whereas, considered over the entire contributing area of a watershed, they control surface water and groundwater quality [58]. Hydropedology addresses the boundary between the pedosphere and hydrosphere with an interand multi-disciplinary approach. One fundamental scientific issue is the impact of soil structure and horizonation ([59] comprehensively explains the additional fundamentals of Hydropedology). For example, runoff generation in low mountain ranges is strongly influenced by the lateral fluxes of soil water caused by periglacial cover beds $[60,61]$. Here, stratified soils not only generate a preferential lateral interflow, but the soil architecture in particular influences the geochemical transport of substances, e.g., the depth distribution of trace element concentrations depends on lithological discontinuities in soils [62-64]. Hydropedology also encompasses the important linkages and feedback mechanisms between soil development, water movement, and the response of ecosystems at different spatio-temporal scales [65]. As ecosystems, soils are also habitats for different biota, just as soil itself is a living entity and not just abiotic material based on physical and chemical weathering processes [35]. Furthermore, plants, fungi, and animals have had profound effects on the rate of mineral weathering [66]. The coupled cycles approach within the CZ concept supports an integrative research concept in Hydropedology, because the hydrological cycle is inseparable from the biogeochemical cycle, strongly influenced by biota, which together determine the ecological cycle [35]. 
Hydrological Processes

Water

Spring discharge (quantity)

Spring water contents (quality)

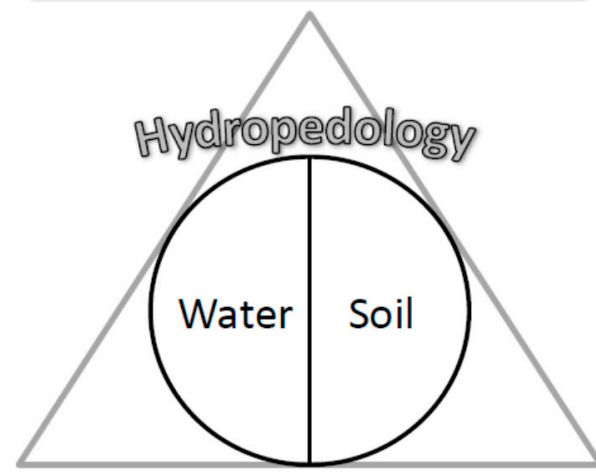

Pedological Processes Geomorphological Processes

Soil

Spring microhabitats

Spring-allochthonous nutrients

Landscape

Spring types

Island habitat

Figure 3. Hydropedology as an interdisciplinary science in the context of spring ecology (modified after [35]).

Springs are often directly embedded in the soil surface, except where the springhead discharge is related to rock. Nevertheless, springs, as autonomous aquatic habitats, are mostly a component integrated into the upper soil layer. For example, gleysols are especially related to the occurrence of groundwater up to the existence of springs. Springs' hydromorphological structures are influenced by soil parameters, such as the grain size of mineral substrates and the quantity of organic matter, in addition to the physicochemistry of the water and biota distribution [43]. This means that pedological processes are relevant for supplying different materials for spring microhabitats and spring-allochthonous nutrients (Figure 3, Pedological Processes: Soil). Substrate types functioning as spring microhabitats and the $\mathrm{CZ}$ are their supplying system. Here, the weathering engine of the $\mathrm{CZ}$ transforms bedrock into soil as a basis for substrates [67]. Furthermore, vegetation in the $\mathrm{CZ}$ delivers organic substrates, which are the raw materials for biological mineral-organic processes in decomposition or biogeochemical conversion [58]. If the $\mathrm{CZ}$ is the supplying system, spring ecotones themselves are receiving systems. To describe matter fluxes in the system, [43] use the term adjacent ecological systems, in which one is the donor (CZ) and the other the recipient (springs). The authors in [68] point out that spring waters with greater interflow are hydrochemically different from those predominantly fed by baseflow, which means that the flow paths and the retention time in soils have a significant impact on chemical composition. Thus, hydrological processes, including the hydrogeological structures and the geochemical properties of aquifers, influence spring discharge and the composition of spring water contents (Figure 3, Hydrological Processes: Water). Aquifers' hydraulic properties are especially relevant for the actual amount of water (e.g., in $\mathrm{mg} / \mathrm{L}$ ) and for the long-term regimes of spring discharge $[69,70]$. Hydrochemical conditions in spring water quality vary with seasonal fluctuations in discharge and are also influenced by surface runoff from snowmelt [71] (for a discussion of aquifer hydrochemistry in different types of bedrock see [2]). Some spring typologies, which place emphasis on the ecohydrological importance of water flow conditions from lotic (flowing waters) to lentic (standing waters) systems [23,24,72], were established by considering geomorphologic processes or properties such as slope inclination, relief form, tectonic features, and rock structures (lithological properties). These paradigms are typically related to processes and dynamics in landscapes 
(Figure 3, Geomorphological Processes: Landscape). Here, springs are fragmented island habitats within an extensive biome (e.g., forest, grassland, floodplain, or bog) [73] and serve as refuge for endangered species (e.g., stenothermic invertebrates, such as glacial relict species). Colonization and migration for a spring-specific fauna and the composition of its zoocoenoses (predominantly invertebrates) is mostly limited to the connectivity and ecohydrological conditions (e.g., relatively constant cold water temperature) within the aquatic groundwater-surface water boundary and also depends on the surface water types and their network [74]. These effects of the landscape paradigm regarding spring ecology can also be considered a naturally patchy distribution [75] as defined by the patch dynamics concept in landscape ecology $[76,77]$. Patchiness is characterized by substrate-type diversity, and can lead to a higher microhabitat diversity and uniqueness of springs, which can significantly influence biodiversity [78] (see also habitat diversity hypothesis by [79]). The range of heterogeneity is an indication for the degree of contrast in substrate-type diversity, and is a typical ecotone characteristic for pristine or anthropogenically undisturbed ecosystems [80].

\subsection{The Springscape: Spring Habitats as Part of the Landscape}

The integration of diverse patterns, processes, and key factors in analyzing spring habitats at different scales requires a hierarchical framework, such as a spatial basis concept. In terms of landscape research, hierarchically structuring scales provide spatial constructs to reduce complexity [81]. Proper scales and measurements of environmental features form an important foundation of habitat analysis and model development [82]. A hierarchical approach is especially useful and expedient for biota-habitat relationships, because it indicates how these relationships can be studied, depicted, modeled, and applied along a continuum of resolution (e.g., for a habitat quality assessment [83]). A hierarchical spatial framework is more than a geospatial concept; it should also indicate related methods for choosing parameters for fieldwork and laboratory analysis for the appropriate spatial level or scale. Outstanding examples of the continuum of resolution for, e.g., rivers include from headwaters to mouth [84] or the valley rules the stream [85]. These examples imply the integration of a river's linear or network structure into the landscape or the catchment as an extensive area. Catchments are portions of the landscape where the local habitat and biological diversity of the streams and rivers are particularly influenced by landform and land use within the surrounding valley at multiple scales [86]. These riverine landscapes are termed Riverscapes [87,88], which can be studied over a wide range of scales from a stream system to a microhabitat system. The authors in [28,32] propose a comparable approach for forest springheads, introducing the term Springscape. It is the first hierarchical framework concept for springs that illustrates a comparison of different terms about geographical dimensions and scales in landscape ecology and hydrology. Furthermore, the differentiation between spatial levels in the Springscape concept allows us to classify heterogeneous spring habitats into a variety of substrate-type-based microhabitats below the topic dimension. This is necessary in respect to the fundamental request of progress in understanding how organisms respond to patchiness and the need for more realistic conceptions that explicitly recognize the hierarchical layering of patch structures [89].

Springheads and springbrooks are two different geographical entities on the topic level [90] (Figure 4). Biocoenotic classification and zonation for stream waters [91] differentiate between springhead and springbrook based on their dissimilar communities: eucrenal in the former and hypocrenal in the latter. This is important to recognize, because Springheads are crucial for headwater regions, as they are the source of headwater streams and their network system. Springheads are comparable to the reach system of running water on the patch scale [28]. Springbrooks connect downstream reaches to headwaters. Together, springbrooks and springheads form spring areas, which are critical for processing organic matter and nutrient cycling, and may be vital for maintaining a very good water quality throughout the whole of a river network [18]. A spring area is equivalent to the segment system within the hierarchical organization of a stream system [28]. Spring areas are commonly distinguished on the basis of soil types (or hydrotopes) or land use types, a clear connection with hydropedological properties and processes. Here, spring areas, as a combination 
of two separate entities (springhead and springbrook), are related to the chorological geographical dimension or the landscape scale regarding the patch dynamics concept (Figure 4). Spring areas link to minor river basins on a firstly macroscopic hierarchical spatial level. Minor river basins within a catchment area are less than 100 ha in size and are generally associated with headwater streams and network systems, so that those catchments (cf. stream systems [28]) are considered closely together with headwater regions [92] (cf. right illustration headwater region in Figure 4). Headwater regions are a part of major river basins or larger stream networks at the regional geographical dimension related to the landscape scale. Zooming out to the regional dimension gives the perspective that small water types of headwater regions, such as springheads and springbrooks, function as refuges for endangered species, biodiversity hot spots, support systems of clean water, critical sources of organic matter, and donators of recreational opportunities $[18,93,94]$. The upper macroscopic hierarchical level is the geospheric geographical dimension of continent-scale river basins, which are influenced by climate zones. Here, patch scale-based parameters are negligible for understanding properties driven at the global scale. The patch-scale Springscape concept is particularly useful for filling a gap in the hierarchical frameworks for spring ecotones as small water types, in which there is an obvious spatial characteristic of a springhead as a mosaic-structured patch of diverse substrate types. Examining it at the subtopic scale enables further consideration of the habitat scale of the patch dynamic concept and the related spatial distribution of microhabitats and their ecological functions, in addition to making the construction of a theoretical basis for associated spatial research questions in spring ecology possible. The composition of an entire springhead's substrate complex can be related to the patch scale, and the individual substrate type is within the nanoscale range at the habitat scale [28]. Here, microhabitat-fauna relationships can be studied within relatively homogenous substrate types (e.g., woody debris, coarse particulate organic matter or stones), and their potential for colonization by invertebrates as microhabitat specialists can also be studied. Further downscaling and differentiation at the subtopic dimension or habitat scale is conceivable and useful for microbiological research. Spring microhabitat types can be separated in mineral-organic complexes and on a particle and mineral scale as a nanoscale entity. The microscopic scale is relevant for research questions regarding individual micro-organisms or microbiological communities, such as biofilm and their relation to substrate, to study and understand substrate-specific microbial consortia and their colonization of substratum $[95,96]$. The latter is important in understanding the rates of nutrient uptake (e.g., within the nitrogen cycle on the river continuum), storage, regeneration, and export in headwater regions [16].

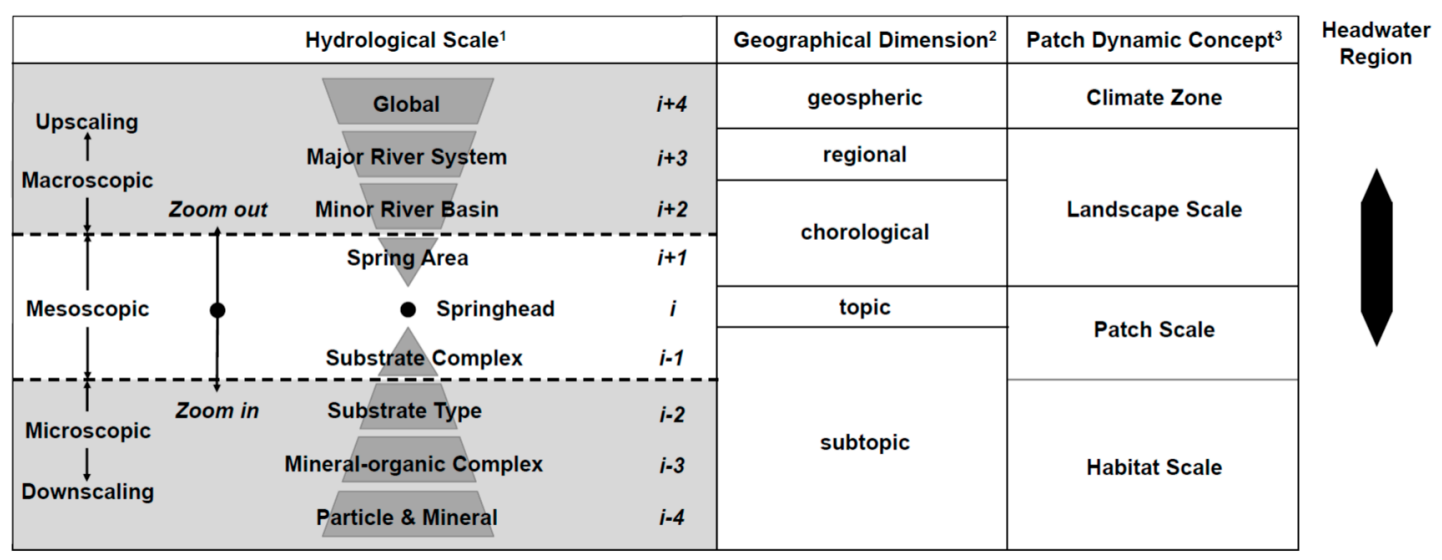

Figure 4. A hierarchical framework of the Springscape within the Critical Zone concept for bridging multiple scales from a micro- to a macroscopic level (inspired by [35], basic idea see [27]). Superscripts refer to 1: [28]; 2: [90]; 3: [76]. Headwater regions mainly belong to minor river basins, spring areas, and springheads, as part of major river basins there connect to the regional scale and vice versa, while springheads are the source of headwater streams connected to the subtopic scale (right). 


\section{Conclusions}

Springs are an integrative part of the Earth's Critical Zone (CZ), the near surface environment in which complex interactions involving rock, soil, water, air, and living organisms regulate the natural habitat and determine the availability of life-sustaining resources. Important geochemical, physical, and biological processes and reactions occur over different spatial and temporal scales. An essential connector of these processes and reactions is related to the water cycle: spring habitats are a key fabric that links groundwater, soil water, and surface water. Springs are liminal, where the subterranean aquifer-related base flow and soil-related interflow convene to create spring discharge on the Earth's surface. However, the generally accepted definition of springs in the geosciences, as an outlet for groundwater to reach the surface, does not delve deep enough into the concept of Hydropedology. Pedological processes have a direct and qualitative influence on spring habitats in supplying different materials; and spring-allochthonous nutrients as well as soil water (interflow) have an essential quantitative share in relation to spring discharge. Spring flow makes headwaters and headwater regions receive oligotrophic, oxygen rich, and cold water: in a word, high-quality water. The ecological connectivity of water bodies enables aquatic animals to migrate from aquifers to surface waters and within the continuum of surface waters between the limnological zones of the crenal and the rhithral. This very relationship illustrates the theoretical background of a hierarchical, spatially based concept, because springs are more than just outlets on the microscopic patch scale when concerning the aboveground and subterranean catchments on the macroscopic landscape scale. The definition of a Springscape provided in this paper offers a useful basis for studying springs within the integrative and multi-scale biogeological approach as it relates to the concepts of Earth's Critical Zone and Hydropedology.

Acknowledgments: We propose funds for covering the costs or part of the costs to publish in open access via the Open Access Fund of the Philipps-Universität Marburg supported by the German Research Foundation (DFG).

Author Contributions: Martin Reiss conducted the literature search; Peter Chifflard contributed the literature search on periglacial cover beds, valuable discussion, and substantial remarks; and Martin Reiss wrote the paper.

Conflicts of Interest: The authors declare no conflict of interest.

\section{References}

1. Kresic, N. Types and Classification of Springs. In Groundwater Hydrology of Springs; Kresic, N., Stevanovic, Z., Eds.; Elsevier: Oxford, UK, 2010; pp. 31-85.

2. Fitts, C.R. Groundwater Science; Academic Press: Amsterdam, The Netherlands, 2013; ISBN 9780123847058.

3. Alfaro, C.; Wallace, M. Origin and classification of springs and historical review with current applications. Environ. Geol. 1994, 24, 112-124. [CrossRef]

4. Bertrand, G.; Goldscheider, N.; Gobat, J.M.; Hunkeler, D. Review: From multi-scale conceptualization to a classification system for inland groundwater-dependent ecosystems. Hydrogeol. J. 2012, 20, 5-25. [CrossRef]

5. Spitale, D.; Leira, M.; Angeli, N.; Cantonati, M. Environmental classification of springs of the Italian Alps and its consistency across multiple taxonomic groups. Freshw. Sci. 2012, 31, 563-574. [CrossRef]

6. Knight, R.L.; Notestein, S.K. Springs as ecosystems. In Summary and Synthesis of the Available Literature on the Effects of Nutrients on Spring Organisms and Systems; Brown, M.T., Reiss, K.C., Cohen, M.J., Evans, J.M., Inglett, P.W., Inglett, K.S., Frazer, T.K., Jacoby, C.A., Phlips, E.J., Knight, R.L., et al., Eds.; University of Florida Water Institute: Gainesville, FL, USA, 2008; pp. 1-52.

7. Glazier, D.S. Springs. In Encyclopedia of Inland Waters; Likens, G.E., Ed.; Elsevier: Oxford, UK, 2009; pp. 734-755.

8. Sanders, D.; Wertl, W.; Rott, E. Spring-associated limestones of the Eastern Alps: Overview of facies, deposystems, minerals, and biota. Facies 2011, 57, 395-416. [CrossRef]

9. Cantonati, M.; Füreder, L.; Gerecke, R.; Jüttner, I.; Cox, E.J. Crenic habitats, hotspots for freshwater biodiversity conservation: Toward an understanding of their ecology. Freshw. Sci. 2012, 31, 463-480. [CrossRef]

10. Pentecost, A.; Jones, B.; Renaut, R.W. What is a hot spring? Can. J. Earth Sci. 2003, 40, 1443-1446. [CrossRef] 
11. Davy-Bowker, J.; Clarke, R.T.; Johnson, R.K.; Kokes, J.; Murphy, J.F.; Zahrádková, S. A comparison of the European Water Framework Directive physical typology and RIVPACS-type models as alternative methods of establishing reference conditions for benthic macroinvertebrates. Hydrobiologia 2006, 566, 91-105. [CrossRef]

12. Ellenberg, H. Vegetation Mitteleuropas mit den Alpen in Ökologischer, Dynamischer und Historischer Sicht; Ulmer: Stuttgart, Germany, 1996; ISBN 978-3-8252-8104-5.

13. Cantonati, M.; Angeli, N.; Bertuzzi, E.; Spitale, D.; Lange-Bertalot, H. Diatoms in springs of the Alps: Spring types, environmental determinants, and substratum. Freshw. Sci. 2012, 31, 499-524. [CrossRef]

14. Nascimbene, J.; Thüs, H.; Marini, L.; Nimis, P.L. Freshwater lichens in springs of the eastern Italian Alps: Floristics, ecology and potential for bioindication. Ann. Limn. Int. J. Limn. 2007, 43, 285-292. [CrossRef]

15. Boulton, A.J.; Findlay, S.; Marmonier, P.; Stanley, E.H.; Valett, H.M. The functional significance of the hyporheic zone in streams and rivers. Annu. Rev. Ecol. Syst. 1998, 29, 59-81. [CrossRef]

16. Peterson, B.J.; Wollheim, W.M.; Mulholland, P.J.; Webster, J.R.; Meyer, J.L.; Tank, J.L.; Martí, E.; Bowden, W.B.; Valett, H.M.; Hershey, A.E.; et al. Control of nitrogen export from watersheds by headwater streams. Science 2001, 292, 86-90. [CrossRef] [PubMed]

17. Snyder, C.D.; Webb, J.R.; Young, J.A.; Johnson, Z.B. Significance of Headwater Streams and Perennial Springs in Ecological Monitoring in Shenandoah National Park; U.S. Geological Survey Open-File Report No. 2013-1178; U.S. Geological Survey: Reston, VA, USA, 2013.

18. Lowe, W.H.; Likens, G.E. Moving headwater streams to the head of the class. BioScience 2005, 55, $196-197$. [CrossRef]

19. Odum, E.P. Fundamentals of Ecology; Saunders: Philadelphia, PA, USA, 1953; ISBN 9780534420666.

20. Cantonati, M.; Ortler, K. Using spring biota of pristine mountain areas for long-term monitoring. IAHS Publ. 1998, 248, 379-385.

21. Reiss, M.; Martin, P.; Gerecke, R.; von Fumetti, S. Limno-ecological characteristics and distribution patterns of spring habitats and invertebrates from the Lowlands to the Alps. Environ. Earth Sci. 2016, 75. [CrossRef]

22. Wetzel, R.G. Limnology: Lake and River Ecosystems; Academic Press: San Diego, CA, USA, 2001; ISBN 9780127447605.

23. Steinmann, P. Praktikum der Süßwasserbiologie; Bornträger: Berlin, Germany, 1915.

24. Thienemann, A. Hydrobiologische Untersuchungen an Quellen. Arch. Hydrobiol. 1924, 14, 151-189.

25. Williams, D.D.; Williams, N.E. Invertebrate communities from freshwater springs: What can they contribute to pure and applied ecology? In Studies in Crenobiology. The Biology of Springs and Springbrooks; Botoaneanu, L., Ed.; Backhuys Publishers: Leiden, The Netherlands, 1998; pp. 251-261.

26. Cantonati, M. State of the Art of Biological Research on Springs. Tagungsband Life-Natur-Projekt Kalktuffquellen in der Frankenalb, Germany [Proccedings Life Nature Project Limestone-precipitating Springs of the Frankenalb, Germany]; Landesverband für Vogelschutz in Bayern e.V.: Hilpoltstein, Germany, 2007; pp. 22-23.

27. Reiss, M.; Chifflard, P. Hydromorphology and Biodiversity in headwaters: An Eco-faunistic substrate preference assessment in forest springs of the German subdued mountains. In Biodiversity in Ecosystems—Linking Structure and Function; Lo, Y.-H., Blanco, J.A., Roy, S., Eds.; InTech Open: Rijeka, Croatia, 2015; pp. 223-258.

28. Frisell, C.A.; Liss, W.L.; Warren, C.E.; Hurley, M.D. A hierarchical framework for stream habitat classification: Viewing streams in a watershed context. Environ. Manag. 1986, 10, 199-214. [CrossRef]

29. Ward, J.V. The four-dimensional nature of lotic ecosystems. J. N. Am. Benthol. Soc. 1989, 8, 2-8. [CrossRef]

30. Hawkins, C.P.; Kershner, J.L.; Bisson, P.A.; Bryant, M.D.; Decker, L.M.; Gregory, S.V.; McCullough, D.A.; Overton, C.K.; Reeves, G.H.; Steedman, R.J.; et al. A hierarchical approach to classifying stream habitat features. Fisheries 1993, 18, 3-12. [CrossRef]

31. Snelder, T.H.; Biggs, B.J. Multiscale River Environment Classification for Water Resources Management. JAWRA 2002, 38, 1225-1239. [CrossRef]

32. Reiss, M. An integrative hierarchical spatial framework for spring habitats. J. Landsc. Ecol. 2013, 6, 65-77. [CrossRef]

33. Brantley, S.L.; Goldhaber, M.B.; Ragnarsdottir, K.V. Crossing disciplines and scales to understand the critical zone. Elements 2007, 3, 307-314. [CrossRef] 
34. Banwart, S.A.; Chorover, J.; Gaillardet, J.; Sparks, D.; White, T.; Anderson, S.; Aufdenkampe, A.; Bernasconi, S.; Brantley, S.L.; Chadwick, O.; et al. Sustaining Earth's Critical Zone Basic Science and Interdisciplinary Solutions for Global Challenges; University of Sheffield: Sheffield, UK, 2013.

35. Lin, H. Earth's Critical Zone and hydropedology: Concepts, characteristics, and advances. Hydrol. Earth Syst. Sci. 2010, 14, 25-45. [CrossRef]

36. Tandarich, J.P.; Darmody, R.G.; Follmer, L.R. The pedo-weathering profile: A paradigm for whole-regolith pedology from the glaciated midcontinental United States of America. In Whole regolith Pedology; Cremeens, D.L., Brown, R.B., Huddleston, J.H., Eds.; Soil Science Society of America: Madison, WI, USA, 1994; pp. 97-117.

37. Anderson, S.P.; von Blanckenburg, F.; White, A.F. Physical and chemical controls on the critical zone. Elements 2007, 3, 315-319. [CrossRef]

38. National Research Council (NRC). Basic Research Opportunities in Earth Science; The National Academies Press: Washington, DC, USA, 2001.

39. Brantley, S.L.; Lebedeva, M. Learning to read the chemistry of regolith to understand the critical zone. Annu. Rev. Earth Planet. Sci. 2011, 39, 387-416. [CrossRef]

40. Anderson, S.P.; Anderson, R.S.; Tucker, G.E. Landscape scale linkages in critical zone evolution. Comptes Rendus Geosci. 2012, 344, 586-596. [CrossRef]

41. Richter, D.D.; Mobley, M.L. Monitoring Earth's critical zone. Science 2009, 326, 1067-1068. [CrossRef] [PubMed]

42. Chorover, J.; Troch, P.A.; Rasmussen, C.; Brooks, P.D.; Pelletier, J.D.; Breshears, D.D.; Huxman, T.E.; Kurc, S.A.; Lohse, K.A.; McIntosh, J.C.; et al. How water, carbon, and energy drive critical zone evolution: The Jemez-Santa Catalina critical zone observatory. Vad. Zone J. 2011, 10, 884-899. [CrossRef]

43. Gibert, J.; Dole-Oliver, M.-J.; Marmonier, P.; Vervier, P. Surface Water-Groundwater Ecotones. In The Ecology and Management of Aquatic-Terrestrical Ecotones; Naiman, R.J., Décamps, H., Eds.; United Nations Educational, Scientific and Cultural Organization (UNESCO): Paris, France, 1991; pp. 199-225.

44. Williams, D.D. The spring as an interface between groundwater and lotic faunas and as a tool in assessing groundwater quality. Verh. Int. Ver. Angew. Limnol. 1991, 24, 1621-1624.

45. Banwart, S.A. Save Our Soils. Nature 2011, 474, 151-152. [CrossRef] [PubMed]

46. Beierkuhnlein, C.; Gollan, T. Forschung zu Quellökosystemen an der Universität Bayreuth—Eine Einführung. In Ökologie Silikatischer Waldquellen in Mitteleuropa; Beierkuhnlein, C., Gollan, T., Eds.; Bayreuther Institut für Terrestrische Ökosystemforschung: Bayreuth, Germany, 1999; pp. 1-8.

47. Gibert, J. Groundwater systems and their boundaries: Conceptual framework and prospects in groundwater ecology. Verh. Int. Ver. Angew. Limnol. 1991, 24, 1605-1608.

48. Wohlrab, B.; Meuser, A.; Sokollek, V. Landschaftswasserhaushalt-Ein zentrales Thema der Landschaftsökologie. In Angewandte Landschaftsökologie; Schneider-Sliwa, R., Schaub, D., Gerold, G., Eds.; Springer: Berlin, Germany, 1999; pp. 277-302.

49. Bastian, O.; Beierkuhnlein, C.; Klink, H.J.; Löffler, J.; Steinhardt, U.; Volk, M.; Wilmking, M. Landscape structures and processes. In Development and Perspectives of Landscape Ecology; Bastian, O., Steinhardt, U., Eds.; Springer: Dortrecht, The Netherlands, 2002; pp. 49-112.

50. Frisbee, M.D.; Phillips, F.M.; White, A.F.; Campbell, A.R.; Liu, F. Effect of source integration on the geochemical fluxes from springs. Appl. Geochem. 2013, 28, 32-54. [CrossRef]

51. Lin, H.; Bouma, J.; Pachepsky, Y.; Western, A.; Thompson, J.; Van Genuchten, R.; Vogel, H.-J.; Lilly, A. Hydropedology: Synergistic integration of pedology and hydrology. Water Resour. Res. 2006, 42, W05301. [CrossRef]

52. Lin, H. Hydropedology. Synergistic Integration of Soil Science and Hydrology; Academic Press: Boston, MA, USA, 2012; ISBN 9780123869418.

53. Hole, F.D. An approach to landscape analysis with emphasis on soils. Geoderma 1978, 21, 1-23. [CrossRef]

54. Sommer, M.; Schlichting, E. Archetypes of catenas in respect to matter-A concept for structuring and grouping catenas. Geoderma 1997, 76, 1-33. [CrossRef]

55. Lin, H. Hydropedology. Vad. Zone J. 2003, 2, 1-11. [CrossRef]

56. Bouma, J. Hydropedology as a powerful tool for environmental policy research. Geoderma 2006, 131, $275-286$. [CrossRef]

57. Kutilek, M.; Nielsen, D.R. Interdisciplinarity of hydropedology. Geoderma 2007, 138, 252-260. [CrossRef] 
58. Chorover, J.; Kretzschmar, R.; Garcia-Pichel, F.; Sparks, D.L. Soil biogeochemical processes within the critical zone. Elements 2007, 3, 321-326. [CrossRef]

59. Lin, H.; Bouma, J.; Wilding, L.P.; Richardson, J.L.; Kutilek, M.; Nielsen, D.R. Advances in hydropedology. Adv. Agron. 2005, 85, 1-89. [CrossRef]

60. Chifflard, P.; Kirnbauer, R.; Zepp, H.; Tilch, N.; Didszun, J.; Zillgens, B.; Schumann, A.; Uhlenbrook, S. Tracing Runoff Generation Processes through Different Spatial Scales in Low and High Mountain Ranges. IAHS Publ. 2010, 336, 90-95.

61. Moldenhauer, K.-M.; Heller, K.; Chifflard, P.; Hübner, R.; Kleber, A. Influence of Cover Beds on Slope Hydrology. In Mid-Latitude Slope Deposits (Cover Beds); Kleber, A., Terhorst, B., Eds.; Elsevier: Amsterdam, The Netherlands, 2013; pp. 127-152.

62. Lorz, C.; Phillips, J.D. Pedo-ecological consequences of lithological discontinuities in soils-examples from Central Europe. J. Plant Nutr. Soil Sci. 2006, 169, 573-581. [CrossRef]

63. Reiss, M.; Chifflard, P. Depth function of manganese (Mn) concentration in soil solutions: Hydropedological translocation of trace elements in stratified soils. Eur. J. Soil Sci. 2015, 4, 169-177. [CrossRef]

64. Reiss, M.; Chifflard, P. Impacts of lithological discontinuities on the vertical distribution of dissolved trace elements in stratified soils. Geophys. Res. Abstr. 2016, 18, EGU2016-9152.

65. Young, M.H.; Lin, H.; Wilcox, B.P. Introduction to special section on bridging hydrology, soil science, and ecology: Hydropedology and ecohydrology. Geophys. Res. Lett. 2007, 34, L24S20. [CrossRef]

66. Amundson, R.; Richter, D.D.; Humphreys, G.S.; Jobbágy, E.G.; Gaillardet, J. Coupling between biota and earth materials in the critical zone. Elements 2007, 3, 327-332. [CrossRef]

67. Anderson, S.P.; Blum, J.; Brantley, S.L.; Chadwick, O.; Chorover, J.; Derry, L.A.; Drever, J.I.; Hering, J.G.; Kirchner, J.W.; Kump, L.R.; et al. Proposed initiative would study Earth's weathering engine. EOS 2004, 85, 265-272. [CrossRef]

68. Nebe, W.; Abiy, M. Chemie von Quellwässern in bewaldeten Einzugsgebieten des Erzgebirges. Forstwiss. Centralblatt 2002, 121, 1-14. [CrossRef]

69. Memon, B.A. Quantitative analysis of springs. Environ. Geol. 1995, 26, 111-120. [CrossRef]

70. Manga, M. On the timescales of characterizing groundwater discharge at springs. J. Hydrol. 1999, $219,56-69$. [CrossRef]

71. Soulsby, C.; Malcom, R.; Helliwell, R.; Ferrier, R.C. Hydrogeochemistry of montane springs and their influence on streams in the Cairngorm mountains, Scotland. HESS 1999, 3, 409-419. [CrossRef]

72. Bryan, K. Classification of springs. J. Geol. 1919, 27, 522-561. [CrossRef]

73. Zollhöfer, J.M. Spring Biotopes in Northern Switzerland: Habitat Heterogeneity, Zoobenthic Communities and Colonization Dynamics. Ph.D. Thesis, Swiss Federal Institute of Science and Technology, Zürich, Switzerland, 1999.

74. Czachorowski, S. Methods of recording and faunistical research of spring habitats in Poland. Crunoecia 1999, 6, 63-66.

75. Gathmann, F.O.; Manne, L.L.; Williams, D.D. Spatial patterns in insect community composition in coldwater springs. Aquat. Ecol. 2009, 43, 501-512. [CrossRef]

76. White, P.S.; Pickett, S.T.A. Natural Disturbance and Patch Dynamics: An Introduction. In The Ecology of Natural Disturbance and Patch Dynamics; Pickett, S.T.A., White, P.S., Eds.; Academic Press: San Diego, CA, USA, 1985; pp. 3-13.

77. Townsend, C.R. The patch dynamics concept of stream community ecology. J. N. Am. Benthol. Soc. 1989, 8, 36-50. [CrossRef]

78. Townsend, C.R.; Begon, M.; Harper, J.L. Essentials of Ecology; Blackwell: Oxford, UK, 2008.

79. Lack, D. The number of bird species on islands. Bird Study 1969, 16, 193-209. [CrossRef]

80. Bell, S. Landscape: Pattern, Perception and Process; Routledge: Oxford, UK, 2012; ISBN 978-0415608374.

81. Blaschke, $\mathrm{T}$. The role of the spatial dimension within the framework of sustainable landscapes and natural capital. Landsc. Urban Plan. 2006, 75, 198-226. [CrossRef]

82. Morrison, M.L.; Marcot, B.G.; Mannan, R.W. Wildlife-Habitat Relationships: Concepts and Applications; Island Press: Washington, DC, USA, 2006; ISBN 978-1597260954.

83. Van Horne, B. Density as a misleading indicator of habitat quality. J. Wildl. Manag. 1983, 47, 893-901. [CrossRef] 
84. Vannote, R.L.; Minshall, G.W.; Cummins, K.W.; Sedell, J.R.; Cushing, C.E. The river continuum concept. Can. J. Fish. Aquat. Sci. 1980, 37, 130-137. [CrossRef]

85. Hynes, H.B.N. The stream and its valley. Verh. Int. Ver. Angew. Limnol. 1975, 19, 1-15.

86. Allan, J.D. Landscapes and Riverscapes: The Influence of Land Use on Stream Ecosystems. Ann. Rev. Ecol. Evol. Syst. 2004, 35, 257-284. [CrossRef]

87. Ward, J.V.; Malard, F.; Tockner, K. Landscape ecology: A framework for integrating pattern and process in river corridors. Landsc. Ecol. 2002, 17, 35-45. [CrossRef]

88. Haslam, S.M. The Riverscape and the River; Cambridge University Press: Cambridge, UK, 2008.

89. Kotliar, N.B.; Wiens, J.A. Multiple scales of patchiness and patch structure: A hierarchical framework for the study of heterogeneity. Oikos 1990, 59, 253-260. [CrossRef]

90. Neef, E. Topologische und chorologische Arbeitsweisen in der Landschaftsforschung. Petermanns Geogr. Mitt. 1963, 107, 249-259.

91. Illies, J.; Botosaneanu, L. Problèmes et Methodes de la Classification et de la Zonation Ecologique des Eaux Courantes, Considerées Surtout du Point de vue Faunistique; Schweizerbart: Stuttgart, Germany, 1963.

92. Clarke, A.; Mac Nally, R.; Bond, N.; Lake, P.S. Macroinvertebrate diversity in headwater streams: A review. Freshw. Biol. 2008, 53, 1707-1721. [CrossRef]

93. Alexander, R.B.; Boyer, E.W.; Smith, R.A.; Schwarz, G.E.; Moore, R.B. The role of headwater streams in downstream water quality. J. Am. Water Res. Assoc. 2007, 43, 41-59. [CrossRef] [PubMed]

94. Richardson, J.S.; Danehy, R.J. A synthesis of the ecology of headwater streams and their riparian zones in temperate forests. For. Sci. 2007, 53, 131-147.

95. Costerton, J.W.; Lewandowski, Z.; Caldwell, D.E.; Korber, D.R.; Lappin-Scott, H.M. Microbial biofilms. Ann. Rev. Microbiol. 1995, 49, 711-745. [CrossRef] [PubMed]

96. Beier, S.; Witzel, K.P.; Marxsen, J. Bacterial community composition in central European running waters examined by temperature gradient get electrophoresis and sequence analysis of $16 \mathrm{~S} \mathrm{r}$ RNA genes. Appl. Environ. Microbiol. 2008, 74, 188-199. [CrossRef] [PubMed]

(C) 2017 by the authors. Licensee MDPI, Basel, Switzerland. This article is an open access article distributed under the terms and conditions of the Creative Commons Attribution (CC BY) license (http:/ / creativecommons.org/licenses/by/4.0/). 